\title{
Credit Institutes' Disclosure and Presentation of Derivatives after the Crisis
}

\author{
Daniele Gervasio $^{1} \&$ Damiano Montani ${ }^{1}$ \\ ${ }^{1}$ Università degli Studi di Bergamo, Italy \\ Correspondence: Daniele Gervasio, Università degli Studi di Bergamo, Italy. E-mail: daniele.gervasio@unibg.it
}

Received: December 9, 2016

Accepted: January 20, 2017

Online Published: January 26, 2017

doi:10.5539/ijbm.v12n2p123

URL: http://dx.doi.org/10.5539/ijbm.v12n2p123

\begin{abstract}
Asked to reconstruct and interpret the causes of the current global crisis, an archaeologist of the fourth millennium could easily find himself sifting through the deluge of publications on the subject of financial instruments known as "derivatives".

The study analyses the disclosure methods adopted for derivative instruments reported in the balance sheets of major banks in central and southern Europe in the period from 2005 to 2012 for the purpose of outlining the types and methods of use in the trading markets amongst retail investors and bank intermediaries.

In the light of the analysis conducted, it is possible to observe how the recent financial crisis has not changed the negotiation strategies of the international banking system with regard to derivatives; financial institutions reputed to be amongst the most famous in Europe are, in fact, still intoxicated by these derivative instruments.

This paper presents an empirical-analytical approach with a series of keys to understanding the derivative market today in the post-crisis period.
\end{abstract}

Keywords: derivatives, financial instruments, securitization, financial crisis

\section{Introduction}

The financial systems of all western countries and beyond have been marked over the last decades by intense innovation of a financial nature. The evolution of regulations, changes in the operational and organisational frameworks of financial intermediaries, progress in risk management techniques, technological developments in communication and data processing systems and the gradual integration of financial systems have all encouraged a constant and pervasive process of innovation which is depicted more and more as both a structural phenomenon of the financial systems as well as the main force behind their changes.

The birth and development of the credit risk transfer market represents one of the innovations. This market, characterised mainly by operations of securitization and credit derivatives, allows the lender (financial intermediary) to transfer the credit risk underlying the credits issued to others. However, the development of such a market has contributed towards changing the distinguishing features of the traditional financial intermediation business to the point of fostering systemic and global forms of financial instability. The financial crisis which erupted in 2007, represents the fragility of the financial system. This fragility has undermined the very foundations of the national and international financial systems, triggering a systemic loss of trust and a blow to the reputation of financial intermediaries.

The lack of trust shown by public opinion worldwide towards financial markets often leads to a form of "financial Luddism", which sees the derivative instruments as the cause of the crisis rather than their inappropriate use by investors and intermediaries.

This study analyses the derivative instruments reported in the balance sheets of major banks in central and southern Europe in the period from 2005 to 2013. The purpose is to present a series of keys to allow an understanding based on an empirical-analytical approach of the derivative market today in the post-crisis period.

\section{References to Derivative Instruments}

The derivative market has reached considerable proportions in the world economy, including Italy, with a value of 650 billion dollars.

However, as Benjamin Lee affirms, "the first problem concerns the production of knowledge of derivatives"; due to the vastness of the relevant financial subject and the haziness created around the product itself, there is still 
too little knowledge of these instruments which is probably due to the fact that some of them are heavily interconnected and in permanent evolution.

Contrary to common opinion, the origin of derivative based contracts dates back to ancient times and various examples can be found in ancient history of negotiations recalling derivative contracts.

In 580 b.c. - Aristotle relates that Talete di Mileto made a fortune by stipulating in the winter (when demand for use was obviously low) an option on the use of some mills in the autumn (a period of heavy demand, even more so that year because there had been an abundant harvest).

Another example states that in 1164 Genoa sold the future tax income for several years to a bank (Monte) in exchange for an immediate advance payment. In this way, the first derivative based contract was drawn up by a local Authority.

However, the popularity of derivative-based contracts became more widespread in modern times when forward contracts were permitted for negotiation at the Royal Exchange in London (which was followed by the first speculative bubble regarding the so-called "tulip mania" in 1637), while the first 'futures' were traded at the Osaka rice market (Yodoya) in about 1650.

Historically, it can be affirmed that the derivative contract developed under the regulations of common law, the doctrine of which defines it as an "alien" contract, in other words "different, strange" and this origin is also clear in its name which derives from the adjective "derivative", a name used by English doctrine to describe those financial instruments based on other instruments that influence its value.

A definition of these contracts is missing from Italian law, that is the primary regulations; the TUF (Consolidated Law on Finance) is limited to specifying that contracts based on derivatives listed in Art. 1, para., 2 lett. d), e), f), $\mathrm{g}), \mathrm{h}$ ), and j) are included amongst the financial instruments.

A little more information is provided on the practice by the Bank of Italy in its circular letter, "Supervisory instructions for banks" n. 229 dated 21st April 1999, section V, Art. 3 which defines derivative contracts as "contracts based on other contractual elements, such as bonds, currencies, interest rates, exchange rates, share indexes, etc.. Their value "derives" from that of underlying elements and futures, options, swaps, and forward rate agreements belong to this category".

Already twenty years ago, Italian literary doctrine used similar terms to investigate the phenomenon of derivatives, defining them as "contracts whose value derives (in other words depends on) the price of an "underlying financial activity", that is to say the value of a financial reference parameter". Of the two definitions referred to above, that of the Bank of Italy is, undoubtedly, the more precise: in fact, the term "derives" could take on a dubious meaning when describing such a type of contract, using national law as a yardstick, given that a derivative contract is not a contract connected to other legal relations, but rather a contact that depends on other transactions.

As observed in doctrine, the subject of the contract is never the "underlying element", but the difference between the value of the reference entity at the time the contract is drawn up and the value assumed by the same entity at the date on which the contract is performed. This leads to the recognition of the derivative as an "essential and qualifying component".

According to international accounting principles, the definition of a derivative instrument is of primary importance given that for financial instruments that can be described as derivatives, such accounting principles provide one single method of evaluation, without any possibility of choice on the part of the entity; the international definition of derivative instruments can be found in IAS 39 which considers them to be a financial instrument with the following characteristics:

- its value changes in response to the change in an underlying variable (underlying asset) that can be of a financial type (interest rate, price of a financial instrument, price of a commodity, exchange rate of foreign currency, price or interest rate indexes) or of a credit type (creditworthiness or credit indexes);

- it requires no initial net investment or it requires an initial net investment that is smaller than would be required for other types of contract from which a similar response would be expected to changes in market factors;

- it is settled at a future date.

It can be noted that IAS 39 is limited to indicating the general characteristics qualifying a derivative instrument, without providing a definition for each type due to the vast number of these products.

Consequently, for the purposes of IAS 39, derivatives must be classified according to the following categories: 
- hedging derivatives which respect the requirements for the application of hedge accounting and for which the company has decided to apply hedge accounting;

- trading derivatives which refer to the derivatives purchased for speculation, which do not follow the rules of hedge accounting or those for purposes of arbitrage.

The main derivatives have as their underlying element the following and can be classified as stated below:

1) Interest rates

2) Foreign currencies

3) Cds

4) Shares

5) Raw materials

6) Other

\section{\$ 504.1 thousand billion}

$$
\begin{array}{lll}
\text { “ } 63.4 & \text { “ } & \text { “ } \\
\text { “ } 28.6 & \text { “ } & \text { “ } \\
\text { “ } 5.9 & \text { “ } & \text { “ } \\
\text { “ } 3.1 & \text { “ } & \text { “ } \\
\text { “ } 42.6 & \text { “ } & \text { “ }
\end{array}
$$

\$ 647.7 thousand billion

From the table, it can be seen that the first three positions are covered by interest rates, followed by the trend in foreign exchange currencies and, finally, Cds - Credit de-fault swap better known as contracts guaranteeing the risk of insolvency of a company or a sovereign state. These instruments, moreover, are traded on the Otc - over the counter market, in other words the unregulated market and they may have a hedging, speculative or arbitrage function becoming, according to the different cases, either simple, structured (or complex) or credit derivatives. As we will see, the entry in the balance sheet differs according to the Italian accounting principles or international accounting principles.

As we have stated, derivatives are mainly used for three purposes:

1) hedging to reduce the market or the financial risk;

2) trading for the sole purpose of gaining a profit;

3) arbitrage, for achieving sure risk-free profits, normally by carrying out opposite sign financial transactions, taking advantage from momentary misalignments between the prices set on different markets.

Over time and with the creativity of financial operators, a wide range of products is now available that enables speculation on absolutely anything. The element which distinguishes (both positively and negatively) the potential effects of derivatives is certainly that of being able to use small amounts to speculate on higher amounts, by means of the so-called leverage which increases by a certain number of times the price of the derivative according to the variation of the underlying element: this can lead to considerable earnings, but also the loss of the whole capital in a few moments.

Derivatives can generally be subdivided into three categories:

1) simple derivatives: simple derivatives (also known as plain vanilla) are the most basic and least complicated as they usually track just one underlying element;

2) complex (or structured) derivatives: a wide variety of products exists created by financial operators arising from combinations of derivatives which are traded Over the counter. They are subdivided into:

- exotic options: the adjective refers to products that are not normally used on our market; in fact they consist of standard options with the application of some variants that modify the structure. The main exotic options are: packages, Bermuda-style options, forward start options, compound options, chooser options, barrier options, binary options, lookback options, shout options, Asian options, exchange options, rainbow options and basket options etc.;

- non-standard swaps, consisting of variables that concentrate on the basic structure of interest rate swaps such as equity swaps, complex currency swaps.

3) credit derivatives: the market of credit derivatives represents the sector of derivative contracts that has undergone major growth. These instruments allow the credit risks to be traded and are used mainly by banks and other intermediaries which, against payment of a sum, can obtain the elimination or lessening of the credit risk on the assets that it holds in its portfolio. The counterpart is usually an insurance company or hedge funds. 


\section{Transparency in Bank Disclosures}

Numerous studies have been carried out up until now to check the possible implications deriving from greater bank transparency. In the past, it was considered that transparency should be used for regulation purposes in order to arouse increased trust on the part of investors in the bank system. Subsequently, transparency assumed a new role. Starting from the main international institutions which promoted an increase in bank disclosures in order to strengthen the discipline of the market, a series of works have been conducted to verify the actual potential of disclosure as a mechanism for controlling banks.

Some authors have argued that disciplining the market by means of greater transparency, may increase the fragility of the bank system and increase depositors' "bank run", leading to serious consequences.

On the contrary, other authors have justified the value of disclosure as an instrument that increases control over the banks. By virtue of this principle, the more information the banks are obliged to reveal, the greater their exposure to the judgement of the market and, consequently, they would have less incentive to adopt imprudent measures. In particular, if consideration is given to the third pillar of Basle 2, the main aim of the new informative obligations concerning the risks of the banks is exactly that of dissuading them from excessively risky management that could generate crises throughout the system. Nier and Baumann support the government policies dedicated to strengthening disclosure, stating that the degree of awareness of the banks' risk choices and, therefore, the greater disclosure of the risks encourages the same to maintain adequate assets to cover the risks taken. Investigating whether transparency increases or reduces the stability of the bank system, Nier reaches the conclusion that the banks that transmit more information are less exposed to the risk of bankruptcy. Furthermore, empirical findings have shown a lower probability of systemic crises in the countries in which more stringent regulations are in force concerning transparency and the auditing of balance sheets. A further passage has also made an estimate of the impact of greater disclosure on the real economy, giving very positive results in this sense.

Yet more authors have reached conclusions lying between those above, affirming that when banks have full control over the volatility of their loan portfolio, then disclosure to the public reduces the probability of bank crises, while when banks do not control their risk exposure, the presence of informed depositors could increase the probability of banks going bankrupt. Starting from the recognition that disclosure is a necessary, but not sufficient, condition for an effective regulation of the market, the essential requirements have been analysed to allow informative transparency to lead to a concrete mechanism for regulating the banks. The debate is still on-going: no full agreement has yet been reached on the effects deriving from increased bank disclosure and the financial community appears to be divided between supporters and opponents of greater transparency.

Examining the topic of transparency from the point of view of the banks, a question arises regarding the effects for the same in terms of costs/benefits.

Important results have been achieved by Baumann and Nier who have demonstrated that the banks disclosing more information, show a lower volatility of their shares compared with less transparent banks. This leads to a benefit for the banks due to the reduction of the cost of capital. However, these results do not take into consideration the significant direct and indirect costs linked to greater disclosure.

A further reflection emerging from existing literature concerns the present-day degree of banks' disclosure which still stands at low levels. With specific reference to disclosure on the question of risks, Geny and Mongiardino believe that "currently, the reports of risk management do not satisfy the standards necessary to be of real use to investors or analysts".

As far as the actual measurement of bank disclosure is concerned, different methods have been adopted in an attempt to overcome the problems linked with the qualitative nature of the disclosure variable and for the purpose of reaching a quantitative measure of the same.

\section{The Methodology}

A description follows of the methodology adopted for analysing the volume of derivatives and their presentation in balance sheet disclosures.

Based on an empirical-analytical approach, the study puts forward a series of keys to understanding what the market of derivatives is today, in the post-crisis period.

\section{- Derivatives business of financial institutions}

Innovations of a financial, technological and organisational nature have had a substantial impact on the ways in which banks govern and organise their financial intermediation business. 
Up until a few years before the outbreak of the Great Crisis, most observers hailed financial instruments for their faculty to make risk management more efficient; today, it is believed that the current financial crisis that has rocked the very foundations of the national and international financial systems, triggering a systemic loss of trust and the reputation of financial intermediaries, arose within the banking business model devoted to optimising the risk-return ratio of the capital invested.

Accounting criteria capable of combining transparency, fairness and coherence with the business carried out by the firms would contribute towards restoring the trust and reputation of the whole economic-financial system.

Numerous studies have been carried out up until now both for studying the possible implications of greater bank transparency and for the purpose of measuring the level of bank disclosure on a national and international level. However, a univocal opinion has yet to be reached regarding the possible effects that greater transparency may have on the banks. On the basis of these statements and considering the wide margins for investigation that the topic still presents today, especially with reference to the Italian context, this work sets out to examine whether there is a connection between the entity of derivatives held by the banks and the presence of supplementary information in the annual reports in terms of transparency.

The hypothesis to be checked refers to the existence of a correlation between the volume of derivatives held by each credit institute and the completeness of the economic-financial information and, therefore, if transparency can be understood as one of the factors contributing towards mitigating the risk inherent in such instruments.

- The reference sample

In order to achieve the objectives of the analysis as detailed above, the investigation examines a sample consisting of the major banks in central and southern Europe which have been identified on the basis of the following characteristics:

- National and European ranking for total assets;

- Number of customers, $>19$ million customers;

- Quotation on the regulated market, where the shares are traded more and are more liquid in order to have more accurate comparisons.

Intesa Sanpaolo and Unicredit have been identified amongst the major national financial intermediaries, whilst Société Générale, Commerzbank and Banco Santander have been selected from amongst the European intermediaries.

On this point, it should be noted that Société Générale was not chosen for its national ranking, occupying as it does third position, but for the volume of derivatives traded.

It was decided to exclude the banks Monte dei Paschi di Siena and Bankia from the sample due to recent company events which would have prevented an objective and precise assessment of the balance sheet from being made.

The investigation examines a series of past balance sheets, starting from the date on which the IAS was introduced (2005) up to the latest balance sheet available.

Compared with the time span defined, the following are exceptions:

a) Intesa Sanpaolo because in 2005 the bank was the subject of a merger; therefore, the sequence of historical data for comparison is available from 2006;

b) Société Générale, owing to the inability to trace some financial reports required for the analysis.

A decision was taken not to limit the research to national borders, but to select other intermediaries from some European States including France and Germany, recognised as flagships of the European economy, and Spain, with a fragile economy and a precarious equilibrium similar to our country.

\section{Main Empirical Evidence}

The left-hand side of the table presents the total trading derivatives compared with the total assets. As some data is not available from the group of banks for 2005 , the table of our selected sample is only partially complete compared with the trading instruments. According to the data at our disposal, the predominance of the German bank can be noticed with as many as $15.41 \%$ of the instruments compared with the total assets, followed by Unicredit (9.25\%) and finally, the Spanish bank Santander (3.42\%). 
Table 1. Assessment of the level of trading/hedging derivatives compared with the total number of assets

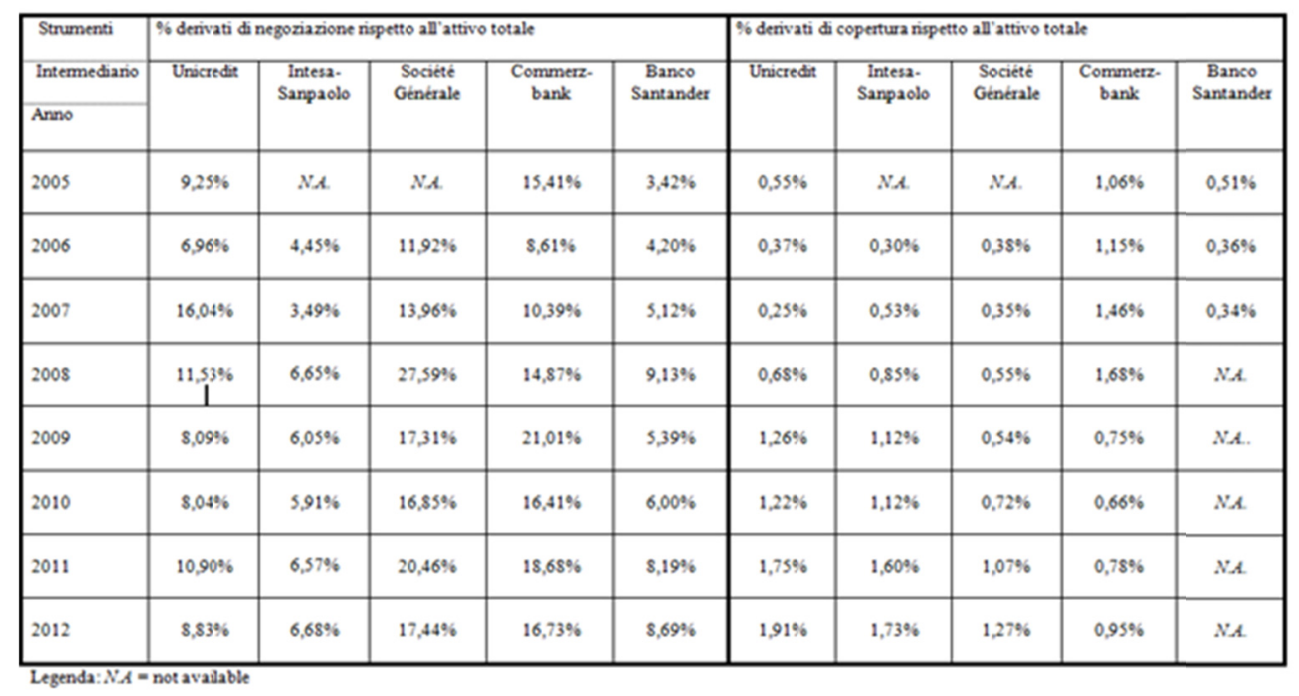

In 2006, a clear image is outlined of the intermediaries and their percentage of trading derivatives compared with the trading assets and this will be seen repeatedly over the course of the following years of the analysis. In the leading positions, we find the French intermediary with $11.92 \%$, followed by the German bank $(8.61 \%)$ and the two Italian banks (6.96\% for Unicredit and $4.45 \%$ for Intesa) and, finally, Banco Santander with $4.20 \%$.

In 2007 an exception is outlined as Piazza Cordusio with 16.04\% steals the position from Société, (13.96\%) and from Commerzbank (10.39\%). Santander (5.12\%) and Intesa (3.49\%) are in last place.

However from 2008 to 2012, the overwhelming return of the German and French intermediaries to the first two positions is evident, with percentages that reach between $14.87 \%$ and $21.01 \%$ for the first and $16.85 \%$ and $27.59 \%$ for the transalpine bank; in these years, Unicredit remains stationary in third place with a minimum of $8.04 \%$ and a maximum of $11.53 \%$, followed almost always by Santander (5.39\%-9.13\%) and then by Intesa (5.91\%-6.68\%).

The comparison between these intermediaries shows how the German and French banks, which are renowned for their reliability, actually make far more use of derivative instruments in their balance sheets compared with the Italian and Spanish banks.

As far as the hedging derivatives are concerned, on the right-hand side of the table, there is no linear trend, but numerous changes of position over the years.

In 2005, Commerzbank was the intermediary that held the most hedging derivatives compared with the total assets $(1.06 \%)$; this bank was followed by Unicredit $(0.55 \%)$ and Santander $(0.51 \%)$. Excluding the latter, for which we have data up until $2007(0.51 \%-0.36 \%-0.34 \%)$, for the banks analysed, a growing annual trend can be noticed in the instruments in the portfolio, with the exception of the German intermediary which, from 2008 with $1.68 \%$, showed a gradual reduction in the hedging derivatives in its balance sheet, reaching the point of being the intermediary with the fewest instruments and with percentages of below $1 \%$ in 2012 .

A further consideration concerns the two Italian banks: as from 2009, both of them decided to increase the quota given to these instruments, leading them to occupy the first two positions in 2012 with percentages nearing $2 \%$. The French intermediary was nearly always in third position with a range of values between $0.35 \%$ and $1.27 \%$.

To understand the reasons that led the Italian and German managements to act in the ways analysed above, it can be presumed that the Italian intermediaries, realising the national economic and financial difficulties, opted for more prudent positions compared with the German banks which were certainly in a more dominant position in Europe and, therefore, less exposed to risk.

Finally, it can be noted how the hedging percentages are much lower than the total assets. We can assume that this low percentage is, in actual fact, fictitious insofar as the banks, to simplify operations, often prefer to include instruments which are really hedging derivatives under the "trading" category. 
Table 2a. Identification of the quoted derivatives not subdivided by category

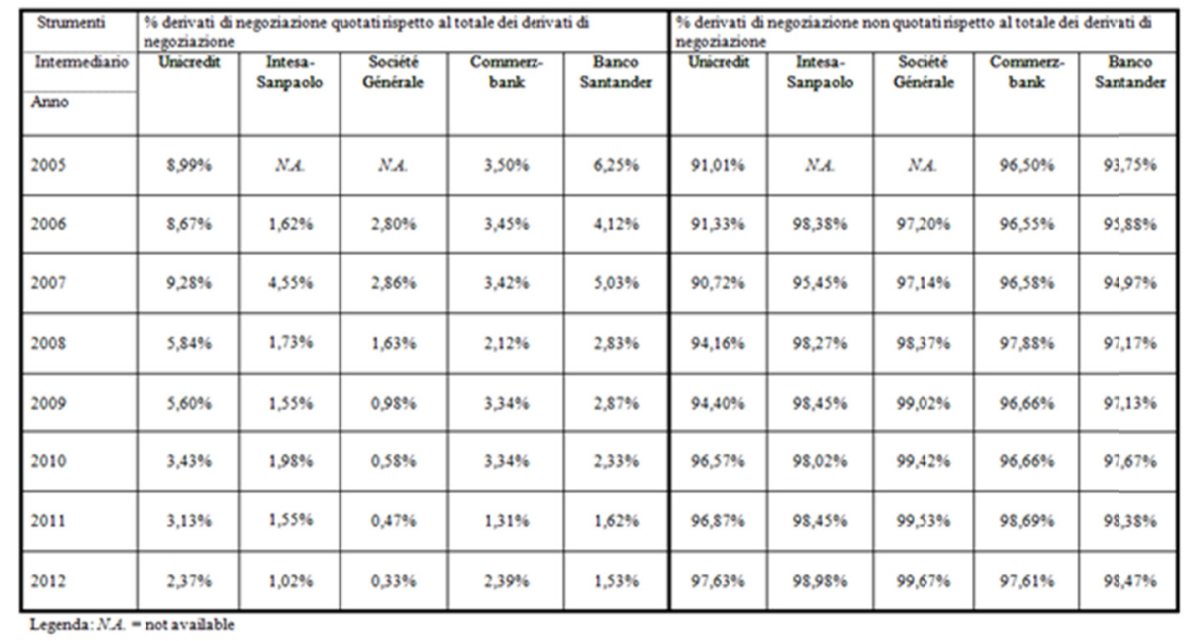

By examining table $2 \mathrm{~A}$ it appears obvious that most trading derivatives are reserved for unlisted instruments as there is no surety against the insolvency of the counterpart. Taking the time span considered as a reference, it can be noted that the French intermediary is in first place with a range of values between $97.14 \%$ and $99.67 \%$, almost always followed by Intesa, with a minimum of $95.45 \%$ and a maximum of $98.98 \%$; the years 2007 and 2011 are exceptions as Intesa is then in third place, having been replaced by Commerzbank. The German and then the Spanish intermediaries follow, alternating each other with values from 96 to $98 \%$. Finally, Unicredit is in last place, having a percentage of the instruments previously described in the balance sheet of between $90.72 \%$ and $97.63 \%$, which are, in any case, high percentages.

At the end of this description, it is extremely obvious how the intermediaries decide to trade mainly on the "OTC" market, leaving minimum percentages to the quoted derivatives (from $0.5 \%$ to $9 \%$ ), which, as previously stated, are instruments reserved primarily for the customers.

Table 2b. Strumenti derivati quotati e non suddivisi per categoria

\begin{tabular}{|l|c|c|c|c|c|c|c|c|c|c|}
\hline Strumenti & \multicolumn{9}{|c|}{$\%$ derivati di copertura quotati rispetto al totale dei derivati di copertura } & \multicolumn{3}{l|}{$\%$ derivati di copertura non quotatinspetto al totale dei derivati di } \\
copertura
\end{tabular}

The hedging derivatives, as shown in table I, represent very limited percentages compared with the banks' assets $(0.30 \%$ to $1.5 \%)$ as the banks seem to prefer trading derivatives. As in table II A, also in this case, the percentages show a preference for the unquoted market. It is believed that this preference for the "OTC" market is mainly due to two factors:

the first, undoubtedly, is the greater volumes of trading derivatives available; in this way, the intermediary is able 
to satisfy its hedging or speculative trading needs which would not be possible on the quoted market due to the low volumes exchanged, as shown in a bank's balance sheet;

the second factor is the presence of more complex instruments that are, therefore, more suitable for banks. Also in this case, these instruments would most probably not be present on ordinary markets.

Table 3. Composition of the commodities of the trading derivatives on quoted markets

\begin{tabular}{|c|c|c|c|c|c|c|c|c|c|c|c|c|c|c|c|c|c|c|c|c|c|c|c|c|c|}
\hline \multirow{3}{*}{\begin{tabular}{|l|} 
Strumenti \\
Intemedanio \\
Sottostante \\
\end{tabular}} & \multicolumn{25}{|c|}{ Denivati di negoriazione quotati } \\
\hline & \multicolumn{5}{|c|}{ Unicasedt } & \multicolumn{5}{|c|}{ Intesa-Sanpaolo } & \multicolumn{5}{|c|}{ Societe Genérale } & \multicolumn{5}{|c|}{ Commerzbank } & \multicolumn{5}{|c|}{ Banco Santander } \\
\hline & -1 & $\delta$ & $\hat{\imath}$ & $?$ & $?$ & -1 & $\bar{\gamma}$ & ถุ & 9 & $?$ & 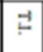 & $\delta$ & ถุ. & $?$ & $\geq$ & $\exists$ & $\delta$ & ถุ. & $?$ & $\geq$ & $\Rightarrow 1$ & 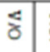 & 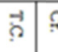 & $\theta$ & $\geq$ \\
\hline 2005 & $\bar{\alpha}$ & 8 & 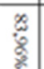 & ళ్ళి & $\begin{array}{l}8 \\
\frac{1}{2}\end{array}$ & $\xi$ & $\xi$ & $\xi$ & $\xi$ & $z$ & $\xi$ & $z$ & $\xi$ & $z$ & $\xi$ & 产 & : & 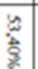 & ళః & క్రి & 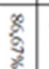 & & 宓 & ళి & $\overline{\bar{k}}$ \\
\hline 2006 & $\frac{8}{20}$ & $\stackrel{?}{\overline{2}}$ & $\begin{array}{l}3 \\
3 \\
3\end{array}$ & ६్ & $\bar{\xi}$ & 受 & ఫ్రి & 离 & 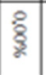 & 宓 & $\overline{\tilde{\breve{u}}}$ & 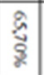 & 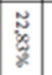 & ڤ్రి & 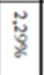 & 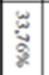 & \& & $\frac{\hat{\vec{z}}}{\bar{z}}$ & ६ి & 言 & 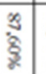 & $\begin{array}{c}\overline{\tilde{N}} \\
\text { 苟 }\end{array}$ & \&్రి & 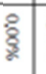 & \&్ \\
\hline 2007 & $\frac{2}{8}$ & 气్రి & $\stackrel{0}{:}$ & $\frac{\circ}{2}$ & $\hat{\S}$ & 产 & $\xi_{\mathfrak{Z}}$ & 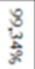 & 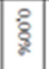 & ڤ్రి & $\overline{\tilde{\breve{v}}}$ & 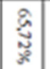 & $\overline{\bar{n}}$ & ఫ్ & 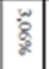 & 然 & : & 落 & 安 & 离 & $\begin{array}{l}x \\
z \\
3 \\
3\end{array}$ & $\overline{\overline{3}}$ & క్రి & ६ి & ళ్రి \\
\hline 2008 & : & 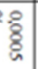 & 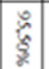 & ఫ్రి & ثै & $\frac{9}{\frac{1}{2}}$ & : & $\begin{array}{l}8 \\
\frac{8}{4} \\
\frac{1}{3}\end{array}$ & 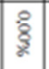 & $\frac{8}{\mathrm{a}}$ & $\overline{\underline{\Xi}}$ & 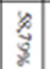 & 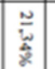 & ఫ్రి & 蓉 & 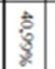 & $\frac{\tilde{n}}{\bar{g}}$ & $\hat{\tilde{z}}$ & 悹 & 这 & 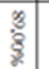 & $\overline{\overline{\hat{z}}}$ & ఫ్రి & ఫ్ & ళ్ \\
\hline & & & & & & & & & & & & & & & & & & & & & & & & & \\
\hline
\end{tabular}

In table 3 a clear distinction is noted in the choices of national and foreign intermediaries.

If for the Italians most of the trading derivatives quoted are part of the "equities" category, Unicredit for example having values which range from $83.96 \%$ to $97.48 \%$ and Intesa with values that are very close to $100 \%$, the other credit institutes or their clients opt for quite different choices.

In the years from 2005 to 2012, most of the French bank's trading derivatives were held in "currencies/gold", the German bank in "equities", even though the percentages are only slightly above $50 \%$, while the Spanish bank concentrated considerably on "interest rates" (between 86.67 and 89\%).

Taken as a whole, a substantial uniformity can be noted in the "equity" category by the Italian and Spanish banks, unlike the greater distribution over the three categories for the other intermediaries.

Small percentages are reserved for the item "other".

The credits columns, on the other hand, are blank.

Table 4. Composition of the commodities of the trading derivatives on unquoted markets

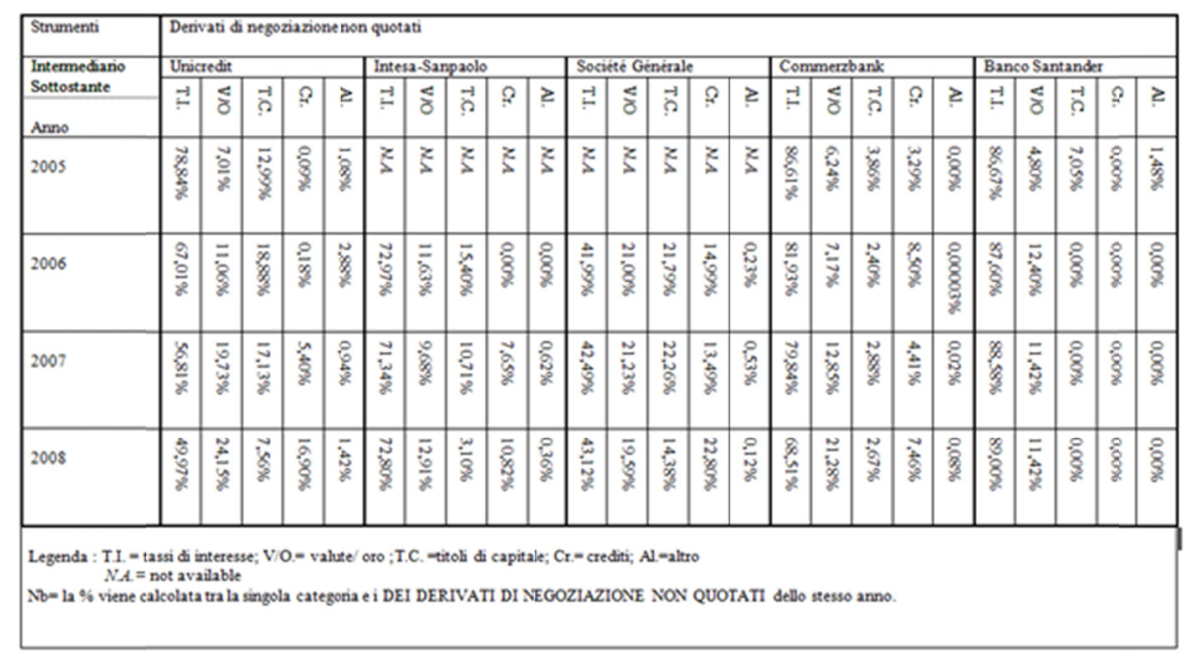

As far as the unquoted trading derivatives are concerned for all the intermediaries, the predominance of the 
"interest rates" category is evident, with percentages for all the banks of above $50 \%$ that in some cases peak at $90 \%$. The only exception is represented by the French bank Société Générale which dedicates about $40 \%$ of its unquoted trading instruments to this category, having a more equal distribution over the other types, with the exception of the section referring to "other" which concerns insignificant percentages of about $0.5 \%$.

Continuing the analysis, it can be seen that for the Italian intermediaries, equities occupy $15 \%$ and are followed by currencies and gold. For the German and the Spanish banks, on the contrary, the second most important category is that of the "Exchange and metals". The credit category assumes greater relevance for the first four intermediaries analysed, with an increasing range over time

$(0.09 \%-22.80 \%)$. The category "other" is again blank, the only exception being Unicredit where it shows percentages of between 0.94 and $2.88 \%$.

From this analysis, it can be sensed that the main business of the banks concerns interest rates in view of the fact that this category maintains a central role every year. These are followed by the trading derivatives in metals/currencies and, finally, equities together with credits, according to the priority established by the management of the bank itself.

The category "other" is probably reserved for those instruments that cannot be clearly classified in one of the previous categories: this would explain the low percentages shown in the table for the samples considered.

Table 5. Composition of the commodities of the hedging derivatives on quoted markets

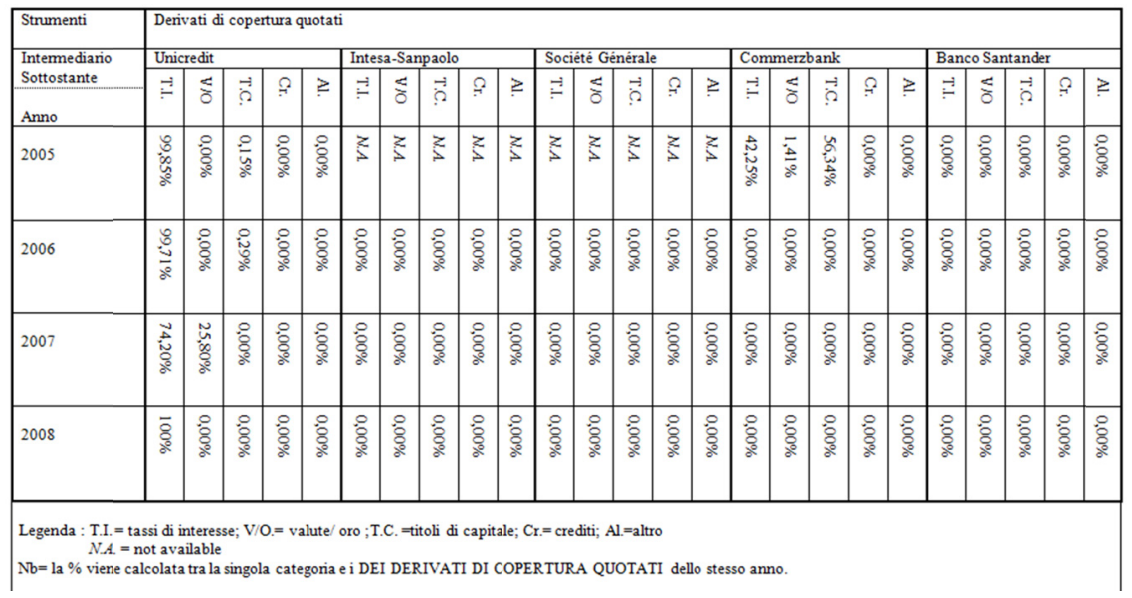

In table 5, the subdivision of the commodities of quoted hedging derivatives is analysed. It is evident that hardly any of the intermediaries use this category: in fact, most of the boxes show a value of nought.

The only exception is Unicredit which, throughout the years taken into consideration, presents this type of derivative in its balance sheet, subdividing most of the instruments into "interest rates" ( $74.20 \%-100 \%)$, except in 2007 in which the "currencies/gold" occupy $25.80 \%$.

For the other intermediaries, only Société Générale held these instruments in its portfolio in 2005, subdividing them into "equities" (56.34\%), "interest rates" (42.25\%) and, finally, "currencies/gold" (1.41\%).

From the data analysed, it is quite clear that these instruments are not chosen by the banks, probably as they are not present in sufficient quantities to be able to guarantee effective hedging and because the intermediaries prefer to purchase on markets with a higher risk.

Also as far as the hedging derivatives are concerned, which occupy between 0.3 and $1.5 \%$ in the balance sheet compared with the total assets, the category on unquoted markets is dominant. From a more careful analysis, it can be seen that the interest rate category plays a leading role for these instruments with percentages varying from $60 \%$ to over $90 \%$, compared with the total. While for Unicredit there is a greater spread towards currencies, gold and equities, Intesa concedes only a small percentage to the latter (2-6\%). The French and Spanish banks also concentrate all the remaining capital on currencies/gold unlike the German bank which implements a distribution that also includes "equities". The columns headed credits and "other" are blank, except for Unicredit which shows percentages of $4.37 \%$ and $12.46 \%$ in the first two years. 
Table 6. Composition of the commodities of the hedging derivatives on unquoted markets

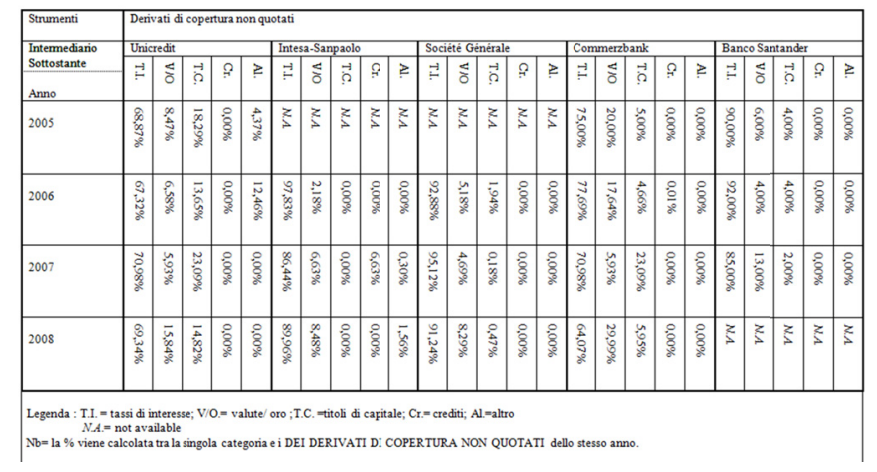

\section{Conclusions}

Innovations of a financial, technological and organisational nature have affected quite substantially the ways in which the financial institutions govern and organise financial intermediation activities. The current financial crisis arose within the bank business model defined as "originate and distribute" and it has shown the complex mechanisms connecting a segment of the real economy (the property market) with the national and international financial economy due to the degree of financial integration that characterises modern national financial systems.

The distorted evaluation of the risks in the overall financial intermediation business, the rise of the "shadow" bank system and the high financial incentive that is implicit in the bank system, as well as speculation represented the elements of fragility of the whole credit risk transfer market and, therefore, of the new models of financial intermediation.

The development of these innovative forms of credit risk transfer fuelled a financial crisis that rocked the very foundations of the national and international financial systems, triggering a systemic loss of trust and the reputation of financial intermediaries. As a result, a profound reflection both on an academic level and on a professional level has become necessary, not only regarding the evolution of the bank model and on its role in the socio-economic system, but also on the prevalence of a shareholder value. Consequently, a profound change must be made to the way of thinking in order to reconstruct a correct concept of firm and of management, as well as exploit the traditional function that the best Italian business management doctrine has always assigned to banks which is that of a subject of development of the socio-economic system. In fact, the financial system is not an end in itself, but a means to an end and the enticement of enormous earnings distracted the main banks from their traditional role, to the detriment of the prosperity and efficiency of the rest of the economy.

As a result, a strategic reorganization at the basis of the bank intermediaries is necessary which no longer aims at optimising the risk-return ratio of the capital invested and the generation of value for the shareholders and the management.

The new financial regulations and the intrinsic principle of transparency of the financial instruments should prevent derivatives and the system of securitization from placing the whole financial system in danger, by forcing the various leading figures on the credit risk transfer market to make conscious evaluations of the risks.

The new regulatory order based on transparency which is requested of the financial system should reduce both the moral hazard that has spread throughout the financial intermediation chain as well as the incentives that are distorted and misrepresented by conflicts of interest.

It seems that the transparency of the economic-financial communication of the banks is the only remedy that can be adopted; the establishment of the international accounting principles (IAS/IFRS) has made an impact not only as far as accounts are concerned, but also on the management and organisation of the banks.

The supplementary information plays a fundamental role in the company's financial communication, according to the international principles; the latter, in fact, introduce modifications to the accounts system and the presentation of the administrative facts connected with the financial management of such companies.

In particular, the new accounting rules defined by such principles, especially IFRS 9 , which will come into force as from the beginning of 2015, fit into a context characterised by globalisation and the recent crisis to which the financial markets have been exposed. The need has arisen in this sphere for more transparent information which is addressed to a wider audience than just the potential or existing investors and this leads to the need for a report 
to complete the economic-financial notes.

It can be deduced from the provisions of the principles IAS 32, IAS 39 and IFRS 7, that according to the dictates provided by the standards, those interested in the company trend should, theoretically, be able to draw specific and detailed information regarding the risk management policies adopted by the company and the characteristics of the financial operations carried out in clear terms from the notes to the balance sheet.

Numerous studies have been carried out up until now both referring to the possible implications of greater bank transparency and to measure the level of disclosure of banks on a national and international level. However, a univocal opinion yet to be reached regarding the possible effects that greater transparency may have on the banks. On the basis of these statements and considering the wide margins for investigation that the topic still presents today, especially with reference to the Italian context, this work sets out to examine the actual capacity on the part of the sample intermediaries to give notice of the risks to which they are exposed in relation to the volume of derivatives held in their balance sheets.

On this point, reference is made as an example to the analysis of table I, in which it can be observed how these instruments occupy a dominant position in the European economic-financial system; derivatives created only for hedging purposes in the past, are today used for the most varied of reasons, mainly for speculation and for "trading". Hedging, by means of derivatives occupies, in the sample analysed, from 2005 to 2012, percentages between $0.30 \%$ and $1.50 \%$ compared with the total assets, while the speculative business has much higher percentages with an average of between $10 \%$ and $15 \%$, with maximum values of $28 \%$ again compared with the assets.

Therefore, although the recent past has given proof of episodes of profound unbalance in the banks generated by derivatives, as occurred for instance in Monte dei Paschi, and, consequently, that the high risk rate inherent in such instruments is well known, the banks do not seem to have changed their operating strategies, persevering with a high level of negotiations in derivatives.

With reference to the results that emerged from the analysis of the annual reports, particular attention has been given to how the bank institutes analysed disclose the derivatives in their accounts documents: is it possible to detect the presence of derivatives directly from the statement of assets and liabilities or the profit and loss account or is it necessary to read the notes to the balance sheet?

From the study it appears evident that firms prefer to represent the information in the explanatory notes, forcing the reader to read the whole annual report thoroughly and in detail.

Furthermore, the study wishes to underline that the evidence was collected from a well-structured empirical analysis and was often based on details actually presented and not simply from merely reading the disclosures.

The topic underlines how the growing number of disclosures provided in the balance sheets raises certain perplexities concerning the usability of balance sheets that are so thick and full of details and information.

It should be understood that the desired accounting transparency refers to the informative and communicative purpose of the balance sheet details and, therefore, to a qualitative and not a quantitative point of view.

Another aspect that is worth mentioning concerns the disparity of the information seen in the integrative notes between the banks of different European States.

In fact, it appears that within the European Union, a common and uniform imprinting does not exist on the matter of the layout of the notes to the banks' balance sheet.

In fact, despite the application of the same accounting standards, the notes to the balance sheet show some quite considerable differences in the degree of detail of the descriptive information in addition to the numerical data presented therein.

With regard to the documents examined for the purposes of this paper, the Italian informative notes seem to contain a higher level of detail compared with the other banks of the sample: part "b" and part "e" of the integrative notes provide supplementary details and information regarding the accounting data.

The company balance sheet of the French Sociéte Générale appeared very simple and straightforward, but it lacks some information for an in-depth analysis of the report itself, whereas, the balance sheet of Commerzbank appears to be very complete in all the sections analysed, even though it presents some limits in the subdivision of the commodities regarding the years 2005-2008, making it necessary to use the table of "derivative transactions" to draw up an estimate.

The integrative note to the Spanish balance sheet, on the contrary, appears not to be so sophisticated and lacks 
some fundamental information for the purposes of this analysis. In fact, the absence of a distinction between the quoted and unquoted instruments and the lack of an informative note for the year 2008 concerning the hedging derivatives, creates a gap in the information that still has to be filled.

In conclusion, the truly critical point does not seem to be the entity of the derivatives present in the system, but rather the methods for evaluating their risk and the disclosure of the same in the balance sheet.

Therefore, a regulation would be appreciated that gives priority to data which, guaranteeing an easy and quick understanding, informs the investor immediately of the exact classification with the relative perception of the risk, thus preventing excessive information from being converted into voluminous investigations behind which a large quantity of implicit content may be hidden.

Even though the firms are taking steps to apply disclosure correctly, as far as the accounting of financial instruments is concerned, the way ahead is still long, especially with regard to the presentation of data using adequate disclosure criteria.

\section{References}

ABI. (2013). Ias-abi. Bluebook: Bancaria Editrice.

Allegrini, M., Azzali, S., Gaetano, A., Pizzo, M., \& Quagli, A. (2006). Principi contabili internazionali. Torino, Italia: Giappichelli

Amran, M., \& Kulatilaka, N. (2000), Real Options. Strategie d'investimento in un mondo dominato dall'incertezza. Milano, Italia: Etas.

Avegno, I. (2015). Il bilancio bancario IAS/IFRS: Recenti novità. Amministrazione \& Finanza, 30(6).

Azzali S. (2015). Financial reporting and accounting standards (a cura di). Torino, IT: Giappichelli Editore.

BDO-Italy. (2016). IFRS 9: Financial Instruments-Endorsement Status. Italian Accounting Bullettin.

Berglung, J. (2016). Estimating expected lifetime of revolving credit facilities in an IFRS 9 framework. Faculty of Engineering, Land University, Centre for Mathematical Sciences.

Binham, C., \& Dunkley E. (2016). Half of big banks unprepared for accounting shake-up. Financial Times.

Black, F., \& Scholes, M., (1973). The pricing of options and corporate liabilities. Journal of Political Economy n.3. http://dx.doi.org/10.1086/260062

Bottero, S. (2016). Strumenti finanziari derivati. Hedge Accounting: Nuovo trattamento contabile. PMI.

Brunel, V., Crepei, S., Jeanblanc, M. (2015). Expected Credit Loss vs Credit Value Adjustment: a Comparative Analysis. Francia: Università Leonardo da Vinci-laboratorio di finanza. http://dx.doi.org/10.2139/ssrn.2686788

Caputo Nassetti, F., Carpenzano, G., \& Giordano, G., (2001). I derivati di credito: Aspetti civilistici e fiscali. Milano, Italia: Giuffrè Editore.

Caputo Nassetti, F., \& Fabbri, A., (2000). Trattato sui contratti derivati di credito. Milano, Italia: Egea.

Carpenzano, G. (2007). Titoli non partecipativi e operazioni fuori bilancio. Corriere Tributario volume, 30(12).

Chan, S. (2016). From IAS 39 to IFRS 9: More Than Just a Name Change. BDO Hong Kong. http://www.hkicpa.org.hk/file/media/section2_become_a_hk_cpa/recog-oversea-bodies/useful-article/namechange.pdf

Corasaniti, G., (2013). Gli strumenti finanziari nella fiscalità d'impresa. Milano, Italia: Egea.

Costantino, G., Caprara, C., \& Vergani, D. (2016). L'impairment dei crediti nell'IFRS 9: sfide e soluzioni. Rivista Bancaria-Minerva Bancaria, 72(2/3).

Cox, J., Ross, S., \& Rubinstein, M., (1979). Option pricing: a simplified approach. Journal of Financial Economics n.7. http://dx.doi.org/10.1016/0304-405X(79)90015-1

Damien, B. (2016). IFRS 9: Ready or Not? Accountancy.

De Nova, G., (2009). I contratti derivati come contratti alieni. Riv. Dir. privato.

De Nova, G., (2011). The law which governs this Agreement is the Law of the Republic of Italy: Il contratto alieno, Judicium.

Dezzani, F., Biancone P., \& Busso D., (2010). IAS/IFRS. Milano, Italia: Ipsoa. 
Dezzani, F., Biancone P., \& Busso D., (2013). IAS/IFRS. Milano, Italia: Ipsoa.

Ferrarese, A., \& Mencaroni, P., (2013). Il codice Salimbeni. Cronaca di uno scandalo MPS. Milano, Italia: La Feltrinelli.

Ferrarini, G., (2010). I derivati finanziari tra vendita a termine e contratto differenziale, in I derivati finanziari, Milano, Italia.

Floyd, N. (2013). High \& Low Finance. New York Times.

Floyd, N. (2013). Wielding derivatives as a tool for deceit. New York Times.

Fortuna, F., (2010). L'informativa sui rischi nelle banche. Milano, Italia: Franco Angeli.

Hegarty, M. (2016). IFRS 9: a complex nut to crack. Risk, 29(5).

Lipuma, E., \& Lee, B. (2004). Financial derivatives and the globalization of risk. Duke University Press. http://dx.doi.org/10.1111/j.1536-7150.2006.00460.x

Lopes, P., Rodrigues, L. (2007). Accounting for financial instrument. A comparison of European companies' practices with IAS 32 and IAS 39. FEP. Working papers, 329. http://dx.doi.org/10.1016/S1052-0457(07)00215-9

Manca, M., (2006). La qualificazione delle operazioni con strumenti finanziari. Il Fisco, 42.

Mechelli, A. (2005). Creazione di valore e stime del risultato di periodo: principi, modelli e metodologie. Milano, Italia: Giuffrè.

Parisotto, R. (2010). IAS 39. Un principio contabile tormentato. Fiscalità internazionale, Italia: Ipsoa.

Pizzo, M. (2000). Il "fair value" nel bilancio d'esercizio. Padova, Italia: Cedam.

Pizzo, M. (2007). Il "fair value" nel bilancio d'esercizio. Padova, Italia: Cedam.

Pucci, S. (2010). L'iscrizione in bilancio delle società quotate delle operazioni di copertura del rischio finanziario. Italia: Giappichelli Editore.

Rainer, M. (2016). The emerging Basel IV: critical points for banks and economy. Bancaria.

Rotili, M. (2016). Il nuovo IFRS 9: analisi critica delle principali innovazioni introdotte. Rivista Bancaria-Minerva Bancaria.

Rutigliano, M. (2016). Bilancio della Banca e degli altri Intermediari Finanziari. Italia: EGEA Editore.

San Lio, M., \& Faienza, A. M. (2016). Per gli strumenti finanziari derivati introdotte le regole contabili basate sul fair value. Corriere Tributario, 39.

Trabucchi A. (2011). Le novità in tema di IAS/IFRS: il D.m. 8 giugno 2011, in M. Leo, Le imposte sui redditi nel testo unico, Commento alle recenti novità in tema IAS, reddito di impresa, CFC, cedolare secca, fondi comuni di investimento e premi di produttività Milano.

\section{Copyrights}

Copyright for this article is retained by the author(s), with first publication rights granted to the journal.

This is an open-access article distributed under the terms and conditions of the Creative Commons Attribution license (http://creativecommons.org/licenses/by/4.0/). 